акредитації. Спеціальності : 7.110101 "Лікувальна справа", 7.110104 “Педіатрія”, 7.110105 "Медико-профілактична справа". - К., 2005. - 54 c.

11. Історія медицини. Програма навчальної дисципліни для студентів вищих медичних закладів освіти III-IV рівнів акредитації. Спеціальність : 7.110106 “Стоматологія”. -К., 2010.-31 с.

12. Кафедра соціальної медицини та медичного менеджменту ОДМУ в період 2003-2008 pр. (до 85-річчя кафедри) / О. В. Козаченко, Б. М. Стречень, В. І. Ткачук [та ін.] // Одес. мед. журнал. - 2009. - № 2. - С. 77-83.

13. Козаченко О. В. Роль і місце історії медицини у вищій медичній освіті на початку XXI століття / О. В. Козаченко // Інститут вищої освіти та його вплив на регіональний розвиток України : соціокультурні, економічні та правові аспекти : матер. міжнар. наук.-практ. конф., 26-27 травня 2008 р. - Ірпінь, 2008. - С. 232-236.

14. Криштопа Б. Проблеми української історії медицини / Б. Криштопа // Агапіт. - 1994. - № 1. - С. 4-6, 33-34.

15. Лисицын Ю. П. Вопросы периодизации истории медицины / Ю. П. Лисицын. - М., 1958. - 38 с.

16. Одесский медуниверситет. $1900-2000$ / за ред. В. М. Запорожана. - О. : ОДМУ, 2000. - 199 с.

17. Преподавание истории медицины в высшей школе : история и современное состояние : матер. Междунар. науч. конф. / [кол. авторов]; под ред. К. К. Васильева. - Сумы : СумГУ, 2007.- 147 с.
18. Сорокина Т. С. История медицины : учебник для вузов / Т. С. Сорокина. - 3-е изд., испр. и дополн. - М. : Academia, 2007.-560 c.

19. Сорокина Т. С. Кредиты и балльно-рейтинговая система в преподавании истории медицины / Т. С. Сорокина // Проблемы соц. гигиены, здравоохранения и истории медицины. - 2006. - № 2. - С. 52-55.

20. Ступак Ф. Я. Вступ до історії медицини. Медицина і первісне суспільство / Ф. Я. Ступак. - К., 2002. - 64 с.

21. Сучасний стан та перспективи розвитку соціальної медицини та організації охорони здоров'я : напрямки та шляхи реформування системи охорони здоров'я (до 80річного ювілею кафедри соціальної медицини, управління та економіки охорони здоров’я) : матер. міжнар. наук.-практ. конф. (Одеса, 18-19 вересня 2003 р.) / ОДМУ; [кол. авт.]; за заг ред. акад. В. М. Запорожана та проф. В. І. Журавля. О. : ОДМУ, 2003.-280с. : іл., табл.

22. Шальнова-Козаченко О. В. Інтерактивні форми навчання при викладанні “Історії медицини”, “Соціальної медицини та організації охорони здоров’ я” : значення для формування майбутніх спеціалістів / О. В. Шальнова-Козаченко // Мед. освіта. - 2010. - № 3. - С. 94-98.

23. Шальнова-Козаченко О. В. Історико-медичні дослідження в публікаціях "Одеського медичного журналу" (1997-2010 рр.) : підсумки та завдання / О. В. ШальноваКозаченко // Одес. мед. журнал. - 2011. - № 1. - С. 54-62.

\title{
ПОЕТАПНІСТЬ НАВЧАННЯ ЛІКАРІВ-ХІРУРГІВ НА КУРСАХ ЕНДОСКОПІЧНОЇ ХІРУРГІЇ В ТЕРНОПІЛЬСКОМУ ДЕРЖАВНОМУ МЕДИЧНОМУ УНІВЕРСИТЕТІ
}

\author{
О. Л. Ковальчук, М. С. Гнатюк, П. І. Шев’як, Ю. С. Сморщок, І. С. Кулянда
}

Тернопільський державний медичний університет імені І. Я. Горбачевського

\section{PHASING OF TRAINING OF DOCTORS-SURGEONS ON COURSES OF ENDOSCOPIC SURGERY IN TERNOPIL STATE MEDICAL UNIVERSITY}

\author{
O. L. Kovalchuk, M. S. Hnatiuk, P. I. Shevyak, Yu. S. Smorshchok, I. S. Kulianda \\ Ternopil State Medical University by I. Ya. Horbachevsky
}

\begin{abstract}
Стрімкий розвиток ендоскопічної хірургії зробив актуальним питання підготовки лікарів-хірургів. На циклі тематичного вдосконалення в Тернопільському державному медичному університеті використовується поетапне засвоєння практичних навичок і теоретичних знань. Хірурги оволодівають практичними навиками в тренажерному залі, під час навчальних операцій на тваринах і в клініці. Такий підхід дозволяє найбільш оптимально засвоїти навчальний матеріал.
\end{abstract}

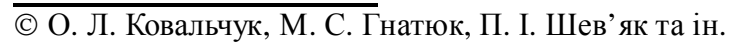


Swift development of endoscopic surgery made urgent a question of surgeons' training. In the cycle of thematic improvement in Ternopil State Medical University is used step-by-step learning practical experience and theoretic knowledge. Surgeons learn practical experience during educational operations on animals and in clinic. Such approach allows to master better course of studies.

Вступ. Останні двадцять років інтенсивно розвиваються нові хірургічні технології, серед яких малоінвазивна хірургія, котра, без сумніву, є одним з найбільших досягнень медицини. Малоінвазивні методи використовуються все ширше, тому що дозволяють досягти максимальних результатів при мінімальній операційній травмі. Сьогодні немає розділу хірургії, де би не були успішно застосовані ендоскопічні технологіі.

Перевагами ендоскопічної хірургії $є$ мінімальна травматичність та низька частота ускладнень, а також істотне зниження строків реабілітації хворого. Складні електронні прилади, спеціальні інструменти дозволяють виконувати оперативні втручання через незначні проколи в тканинах без їхнього розрізу, це вимагає від хірурга додаткових знань та навиків роботи 3 ними. Але наскільки операція стала легшою для пацієнта, настільки ж складною та відповідальною для хірурга.

Тому на перший план виступає пошук нових технологій навчання, які дозволять підготувати висококваліфікованих спеціалістів [1,2].

Максимальний ефект від вивчення будь-якої медичної дисципліни настає тоді, коли лікарі-курсанти не лише отримують глибокі теоретичні знання, але й істотно вдосконалюють практичні навички [3]. Важливе значення у підготовці практичного лікаря надається насамперед освоєнню та поглибленню практичної досконалості, тобто засвоєнню цілого ряду практичних навичок, які пов’ язані із запитами клініки і допомагають виконувати алгоритм різних оперативних втручань.

У вивченні практичних навичок чи будь-якого хірургічного прийому допомагають тренажерні зали, де на спеціальних фантомах можна відпрацювати більшість практичних прийомів, а також виконуючи операції на експериментальних тваринах детально навчитися робити найбільш поширені хірургічні операції.

Відсутність єдиної системи підготовки кадрів для ендоскопічної хірургії, низьке оснащення хірургічних кафедр відповідними наочними засобами стримують темпи розвитку нових технологій. Якість підготовки хірурга при цьому повинна визначатись не довготривалістю перебування його на курсах, а інтенсивністю занять, наявністю умов для тренінгу і якістю викладання.

Метою навчання хірургів є покращення відомих i вивчення нових технологій виконання малоінвазивних операцій. Курсанти повинні виконати такі завдання: а) поглибити знання про причини і механізм розвитку, особливості клінічного перебігу хірургічних захворювань органів черевної порожнини; б) засвоїти та вдосконалити техніку ендоскопічних методик; в) вдосконалити вміння вибору оптимальної та раціональної діагностично-лікувальної програми у хворих із захворюваннями органів черевної та грудної порожнини; г) узагальнити свій досвід 3 прийнятими в державі рекомендаціями з лікування хворих хірургічного, урологічного, онкологічного і гінекологічного профілів за допомогою малоінвазивних технологій.

Основна частина. Для виконання поставлених завдань цикли тематичного вдосконалення “Лапароскопічні та інші малоінвазивні технології в хірургії та урології" та "Лапароскопічні та інші малоінвазивні технології в хірургії та гінекології” розділено на такі етапи. Навчання починається із вивчення теорії сучасних моделей апаратури, спеціального та допоміжного інструментарію, необхідного для виконання операцій, специфіки їхньої обробки та стерилізації. Детально розглядаються анатомо-топографічне обгрунтування малоінвазивних операцій, особливості анестезіологічного забезпечення, показання іпротипоказання, техніка виконання операцій розроблена різними провідними школами.

Одночасно відпрацьовуються практичні навички, що розпочинається з роботи на фантомах в тренажерному залі ендоскопічної хірургії, що оснащений не лише названими вище тренажерами, але і різноманітним інструментарієм та апаратурою, що використовується при виконанні малоінвазивних оперативних втручань. При цьому на фантомах засвоюються та вдосконалюються принципи роботи з інструментами різних фірм, освоюються навики в' язання інтрата екстракорпоральних вузлів. Наявність тренажерного залу ендоскопічної хірургії дозволяє розширити можливості вдосконалення та освоєння необхідних практичних навичок, тому що він дає можливість наочно показати окремі складні етапи названих навиків, а при необхідності багаторазово повторити їх.

Але вміння швидко та якісно виконати хірургічний прийом на тренажері ще не гарантує такий же результат при виконанні операції хворому. Тому важливим етапом у плавному вдосконаленні практики є наступний етап - виконання навчальних операцій на тваринах. Засвоївши особливості роботи з апарату- 
рою та інструментарієм, кожен курсант має можливість виконати в експериментальній операційній діагностичні лапаро- і торакоскопію, холецистектомію, спленектомію, нефректомію, роз'єднання злук, виконати екстра- та інтракорпоральний вузол та шов.

Перед виконанням навчальної операції на тваринах проводиться детальний розбір етапів операції з відеодемонстрацією, порівнянням техніки оперативних втручань різних шкіл, та особливостей їх виконання у тварин. Кожне виконане оперативне втручання на експериментальних тваринах детально розглядається на семінарських заняттях, де детально аналізуються помилки, допущені учасниками операції в алгоритмі виконання того чи іншого оперативного втручання, їхні можливі наслідки під час операції, в ранньому та віддаленому післяопераційних періодах, а також методи попередження допущених помилок, ускладнень та їх корекції.

Опанувавши основні практичні навики, лікарі курсанти беруть участь у виконанні малоінвазивних втручань в клініці, де проходить завершальний етап засвоєння практичних навичок, оскільки ні в тренажерному залі, ні під час навчальних операцій на тваринах не можна передати всі особливості та деталі проведення операції хворому.

На семінарських заняттях обговорюються незрозумілі питання, демонстрація навчальних відеофільмів, з поетапним розбором алгоритмів виконання операцій.

\footnotetext{
Лiтература

1. Ковальчук Л. Я. Основні тенденції розвитку світової вищої школи. Впровадження сучасних технологій у навчальний процес Тернопільської державної медичної академії ім. І. Я. Горбачевського : досягнення і перспективи / Л. Я. Ковальчук// Медична освіта. -2000. - № 2. - С. 5-11.
}

Курсанти мають можливість скористатись послугами бібліотеки, інтранету та інтернету, отримати повну інформацію $з$ навчального предмета, а також інших медичних дисциплін.

3 найбільш важливих і складних тем читаються лекції. Оскільки загальна кількість лікарів-курсантів не перевищує 8 чоловік, а сучасні технології дозволяють використовувати таблиці, слайди, відеофільми, засвоєння матеріалу з використанням наведених етапів навчання є максимальним. Останнє адекватно підтвердилось проведеним анкетним опитуванням лікарів-курсантів.

Наші курси - єдині на території всієї України, де виконуються навчальні операції на тваринах. За період існування курсів з 2007 року навчання закінчили і успішно працюють 270 лікарів-хірургів, урологів, гінекологів, онкологів.

Висновок. Поетапне навчання лікарів-курсантів на курсах ендоскопічної хірургії з відпрацюванням практичних навиків у тренажерному залі, в експериментальній операційній, де проводяться різні оперативні втручання на дослідних тваринах, участь у виконанні малоінвазивних втручань в клініці, детальний аналіз помилок, їх наслідків, ускладнень, їх попередження та корекція, на семінарах та лекціях з найбільш важливих і складних тем $€$ найбільш адекватним, що дозволяє повноцінно освоїти необхідні теоретичні знання та практичні навички з даного розділу хірургії.

2. Ляшук П. М. Про якість підготовки випускників академії / П. М. Ляшук, В. П. Пішак// Медична освіта. - 2000. -№ 2. - С. 22-26.

3. Попович Ю. Л. Техніка хірургічних операцій. / Ю. Л. Попович, К. О. Діамантопуло-Івано-Франківськ, 2005. -348 с. 